\title{
The Marketability of Higher Education Aviation Graduates as Perceived by Regional Airline Pilots
}

\author{
James F. Fullingim, \\ Texas A\&M University Central Texas
}

\begin{abstract}
The purpose of this study was to expose any perceived inadequacies in the higher-education aviation curricula and to propose changes needed to better qualify aviation students in the hiring process at regional air carriers. The research also addressed the assumption that higher education is necessary for advancing a pilot's aptitudes and abilities to perform the highly technical tasks of a professional pilot in a regional airline environment. A survey was used to poll pilots from two regional airlines that were based in Texas. Analysis of the survey responses revealed the perceived quality of training that existed in higher education aviation programs. This confirmed the value of advising a path of higher education for students embarking on an aviation career as a pilot for a regional airline, and that 2-year colleges and 4year universities with aviation programs are meeting the present demands required by regional airlines in the south-central United States.
\end{abstract}

\section{INTRODUCTION}

Aviation collegiate programs have been traditionally viewed as a necessary path for students to obtain a professional aviation background as well as a college degree. In the past, professional pilots had an edge in the aviation market if they held a college degree because this added status to their marketability (Hunt, 1972). Obtaining aviation training from universities that offered aviation programs provided an even more marketable background for pilots and a degree with an aviation emphasis was considered to be even better (Clark, 2006).

Regional airlines hold 2-year colleges and 4-year universities with aviation programs in high esteem. It is also widely held that higher education is necessary for advancing a student's aptitudes and skills to perform the highly technical tasks of a professional pilot in a regional airline environment (U.S. Department of Education, 1998). This is in contrast with individuals that bypass the traditional role of higher education by taking shortcuts in an attempt to prepare themselves as pilots in the airline industry.

Two avenues that appeal to students desiring to obtain their aviation experience in order to prepare themselves for employment at the regional airlines are available at 2-year colleges and 4-year universities. These colleges and universities have specialized aviation programs for students wishing to obtain their flight certificates and ratings in an academic environment while receiving academic credit. Despite the perceived advantage of collegiate aviation programs in preparing students for careers in the airline industry, hiring qualifications for pilots in the regional airline industry have changed from past requirements, and new assessment is needed of the role of collegiate programs in the training of pilots who are entering the air carrier workforce.

The primary purpose of this research was to expose any perceived inadequacies in the highereducation aviation curricula and to propose changes needed to better qualify aviation students in the hiring process at regional air carriers. A secondary goal was to compare and contrast the role of 2-year colleges with aviation programs to the role of 4-year universities with aviation programs in the process of how students are educated for aviation flight careers.

Further scrutiny of higher education aviation programs is needed because of industry demands for greater competency from college flight program graduates entering the regional air carrier workforce (Mangan, 2000). These demands are due to the prevalent use of pure jet aircraft and their technical 
complexity, as well as the changing post-9/11 aviation environment. The increases in costs create training shortfalls and the industry has started to expect aviation universities to take measures to correct these deficiencies (Fanjoy et al., 2005). Already, in Asia, outside aviation training corporations are offering reduced-time types of advanced training courses through the use of computer simulation to teach piloting skills for new air carrier pilots. This type of training is called a multi-crew pilot license (MPL) training program, and it is indicative of one type of innovation being adopted by the air carrier industry (Matthews, 2006). If college program administrators fail to correct deficiencies within their programs, outside aviation training corporation sources will capitalize on the training shortcomings of graduate students that regional airlines expect of new-hire pilots (Mangan, 2000). This will increase the demand of training for future students elsewhere in pilot training corporations, thereby greatly reducing the need and role of aviation universities (Matthews, 2006).

Failure of college programs to adapt to the changes in the aviation industry could result in the cancellation of public higher education aviation programs, which would have numerous negative effects on pilots, including access to cost-effective public programs that over 100 colleges and universities presently offer (Prather, 2006). Other potential negative results from the reduction of collegiate aviation programs will be the emergence of substantially more expensive non-collegiate, commercial aviation schools, a further shortage of qualified pilots for air carrier positions in the United States, and the loss of airline flight operations internship programs that presently provide students with learning experiences that cannot be duplicated in classrooms (Ruiz, 2004).

Understanding the merits of higher education aviation programs is essential to continuing the collegiate path for the preparation of students interested in pursuing air carrier aviation as a career. The present transportation economy and the development of high-tech aeronautical equipment have changed the criteria that regional airlines use to hire entry-level pilots (Fanjoy et al., 2006). This, in turn, has led higher education to modify its aviation curriculum and to better qualify students for future careers in aviation.

\section{REVIEW OF THE LITERATURE}

The literature provides a good indication of what is taught in collegiate aviation courses and it supports the standards that regional air carriers require of aviation graduates. Collegiate aviation has been a major source of training in the United States and this has been recognized by the U. S. Department of Education (1998). Aviation industry leaders have recommended that airlines and universities form partnerships to jointly address the training and technology needs of the air carrier industry (Ruiz, 2004).

One important recent development in collegiate training courses has been the integration of crew resource management training for pilots. The responsibility of working well in a crew environment has best been put to practice in aircraft simulators at aviation universities (Hedge et al., 2000). The flight simulator is a valuable tool that helps prepare students for first officer training in the role of co-pilot during simulated flight sessions, as well as practice in crew resource management skills (Banard, 2000). Other schools have seen the importance of combining aviation courses with a liberal arts curriculum to provide situational awareness to create a better process of crew resource management in the aircraft cockpit (“Several Paths,” 2001).

The events of 9/11 led to catastrophic losses in the air carrier industry, which essentially halted pilot hiring in the U.S. aviation industry. Collegiate aviation programs reacted in numerous ways to keep pilot training aligned with the perceived present and future needs of the air carrier industry. Research showed that some prestigious aviation schools were no better in providing a specialized learning environment for pilot curriculum than outside, self-paced tutorials (Flouris, 2001). This awareness, along with concerns 
about the quality of aviation training in collegiate programs in the U.S., led to numerous attempts at improving the role of training, especially in a down-turned air transportation economy.

During this time, many aviation schools saw a decline in student enrollments. This led to case studies and independent audits to evaluate university programs in parallel with other universities and industry standards, and it also led to searches on how to revise aerospace programs (Schwab, 2005). Colleges have explored new training methods, including the application of distance education in aviation training. Training needs are forecast to grow for aviation at more than $40 \%$, and the need for online learning is seen as a technique to better meet this increased demand (Mahesh et al., 2005). Recent surveys have shown how students select collegiate aviation programs. Based on survey returns, the nine most frequently selected programs and institutional characteristics that attract students to collegiate aviation were program educational quality, university, condition of equipment, institutional educational quality, location of institution, small class size, safety concerns, student to faculty ratio, and distance from home (Clark, 2006).

The literature provides a good accounting of regional airline pilot hiring trends and future hiring considerations. Pilot positions in regional airlines have traditionally been entry-level jobs for collegiate aviation graduates. Regional airlines have a specific hiring criterion that is used to represent the level of flight training of entry-level pilots, while some hiring criteria are relaxed during periods of proficient entry-level pilot shortage (Matthews, 2006). Examples of relaxed times include the heavy use of computer simulation to teach piloting skills, as this reduces the total training time for first officers in the training of glass cockpit operational skills.

Regional airlines respond to positive economic conditions in the U.S. by expanding their routes according to higher public demand for air carrier service. In 1996, airlines earned record profits of \$2.8 billion and carried record numbers of passengers and amounts of cargo (Wells \& Wensveen, 2004). There has been an increase in demand for regional air carrier service and more pilots fly aircraft on these routes (Gilbert, 1994). Regional airlines lowered their minimum flight time requirements for new-hire pilots when they desperately were trying to recruit enough pilots to meet their staffing requirements (Fanjoy et al., 2006). This became more evident after industry expanded the role of smaller regional jet aircraft used in the U.S. air transportation system. These smaller, more efficient aircraft have replaced the older, larger jet aircraft that have been used by the legacy air carriers.

Another issue with huge ramifications is the mandated retirement age for air carrier pilots in the U.S., which is presently set at 65 years of age. The age issue illustrates the split in the airline staffing of pilots. Legacy carriers, struggling with high labor and pension costs, have an interest in replacing higher salaried pilots with younger pilots who earn less (Wolfe, 2005a). A high number of mandated pilot retirements results in a greater need for new pilots at the regional airline level. However, this retirement is highly contested by aviation union groups, which believe that senior pilots are being forced to retire at the peak of their performance and that the safety of passengers is compromised when they are replaced with younger, less experienced pilots.

All of this comes at a time when smaller regional jet aircraft are replacing the larger jet aircraft of the older legacy airlines. The legacy airlines have high fuel costs that are burning up their capital; competition is cutthroat, and two historical mainstays of the industry (Delta Airlines and United Airlines) were forced into bankruptcy (Wolfe, 2005b). Collegiate aviation programs have historically had to adjust their pilot training input to the fluctuating demands of the air carrier market. However, the emphasis of collegiate aviation remains that of offering, training, and graduating a product of excellence in aerospace curricula. 


\section{METHODOLOGY}

To explore the theory that regional airline air carrier pilots with a higher education background have marketability and preferential advantages over pilots without an academic background, a method was designed to ask specific questions of the pilots themselves. This was done by polling specific pilot groups with a user-friendly survey that was completed relatively quickly and anonymously. The style and format of this instrument determined how levels of higher education have aided pilots in modern regional airline pilot positions in the highly technical and demanding air transportation arena.

\section{Population}

The population surveyed for this study was limited to pilots employed at regional airlines, because the regional airlines are the first significant employer for a college aviation pilot graduate. The methodology in this survey was to recruit regional airline pilots in flight position status and to poll their opinions on marketability in the air carrier industry. These pilots represent graduates from 2-year and 4-year institutions with aviation programs, as well as pilots who completed no formal higher education aviation courses. The specific samples came from 2 large Texas-based regional airlines, American Eagle of AMR, Inc., and Express Jet Airlines, Inc. These two regional airlines have vast domestic and international routes across North America and operate both turboprop and turbojet aircraft in their fleets.

\section{Sample}

The initial pilots surveyed at each of these two companies were students who graduated from the Tarleton State University - Central Texas 4-year aviation program and were employed in flight positions. Their employment in the regional air carrier industry was ideal for this study's questions concerning the background of higher education training and how prior training has qualified them for their present occupations as pilot crew members in regional airline air carriers. Along with the aforementioned pilots, other pilot crew members at these various domiciles were contacted by the researcher's graduate aviation students. These crew members were first officers and captains who were employed in the same aircraft types and flight assignments to which Tarleton graduates are assigned. All of these initial pilots were graduate acquaintances of the researcher and performed the same tasks and duties in assigned flight positions at the Dallas-Fort Worth (DFW) and Houston domiciles. This was an accessible method because all pilot employees had personal mail boxes in which the survey instruments were placed.

The domiciles at both the DFW and Houston locations were large, with 940 pilots employed with American Eagle and over 1,000 pilots with Express Jet. The sample size at each location was as few as 30 , with a maximum of 100 . This brought a maximum percentage of $10 \%$ polled at each location, with 200 surveys utilized. The administered sample was a combination of random and convenience. This is because the Tarleton graduate pilots distributed the survey in pilots' workplace mailboxes, as well as physically handed them to the crewmembers they were working with on a particular flight. Because of this personal touch, a high number and percentage of returns resulted.

\section{Research Design}

To properly document the past flight training of pilots who are presently employed at a particular regional airline, a survey instrument was used to collect information from pilots who had been hired by and worked for the respective regional airlines at the time the survey was administered. The instrument surveyed the background and qualifications of the individual pilot who had successfully been interviewed, employed, trained, and placed in a flight position. Questions regarding educational background were specifically included in the survey, along with inquires as to age, gender, and race. Past studies performed with regional airline personnel indicate that these regional airline employers are not overly 
concerned with pilot applicants having a higher education degree or background (Fanjoy et al., 2006). Therefore, the main objective of the survey was to poll individuals who (a) had qualified to be airline pilots; (b) had gone through a regional airline interview process; (c) had been offered and accepted employment with the specific regional airline, followed by successfully completing all phases of company training; and (d) were actively employed as pilots in a flight position.

\section{Instrument}

A pilot survey was developed and field tested on a group of pilots for input and possible modifications. The survey instrument was developed in a Likert scale format that asked the respondents to reply to specific questions pertinent to their aviation background. Additional data questions on the survey were developed in the areas of aviation education, qualifications obtained prior to being hired at their present airline, abilities perceived to be critical in the airline industry, and present job satisfaction. These questions were designed to determine relationships between college status and non-college status and how these backgrounds affected employability. The proposed instrument was a printed questionnaire with a return postage-paid envelope for the respondents to complete. This format was carefully chosen because access to individual pilot inter-office mail boxes was obtainable through graduate pilot acquaintances. Follow-up information on the results of the survey was made available to individuals taking the survey, provided the writer had access to their individual email addresses. The physical paper mail survey was preferred because it offered greater anonymity, less intimidation, less expense to the subject completing the survey, and a higher completion return than the online electronic survey.

As an incentive, a gratuity in the amount of a one-dollar bill was placed in each survey document. This incentive was expected to increase the rate of completion and return for the survey instruments. This particular incentive was chosen over a gift card because the expense was less and the monetary amount was deemed insignificant to be appreciated by the pilot recipients.

\section{Collection and Treatment of Data}

Three graduates from the Tarleton State University - Central Texas Aviation Program had access to this population inside their two workplaces. These packets were either personally handed to the recipients or placed in their company mailboxes. One hundred and three of the 200 distributed surveys were returned by mail during the duration of the study, for a return of $51.5 \%$. All of the returned surveys were entered into an Excel spreadsheet. Forty-seven different columns were used to enter answers for each question. Written comments were all transcribed and entered into one separate column. Procedures utilized frequency and percentage distributions for data analysis on the nominal and ordinal scale. Mean scores and standard deviations on interval data were gathered from the Likert scale questions.

\section{Quantitative Research Related Data Questions}

The first 22 questions of the survey were based on the respondent's opinion regarding past education issues, and the choices for responses were Likert scale selections in a range from 1 to 4 ( 1 = strongly disagree to $4=$ strongly agree). The last selection, five, was not used in tabulating the results. This selection was left on the survey instrument to discourage the person taking the survey from picking an average selection in the middle of the scale. Four themes were designed into the 22 questions: school and academics, satisfaction with academic programs, employment, and workplace opportunities with challenges. From the first 22 questions on the survey, questions 1, 2, 4, 7, 8, 9, 12, 13, 14 and 16 pertained to school and academics. Questions 3, 5, 6, 10, 11, 15, and 17 pertained to satisfaction with academic programs. Questions 19, 20 and 21 pertained to employment. Questions 4, 17, 18 and 22 pertained to workplace opportunities with challenges. 
To determine whether the questionnaire had kept with the issue of pilot marketability in the regional airline industry, the returned answers were tested statistically using the SPSS version 15 exploratory factor analysis to see whether a trend existed among the questions. Of these first 22 questions, 4 themes appeared: school and academics, satisfaction with academic programs, employment, and workplace opportunities with challenges.

Table 1. Factor Analysis for Survey Data: Total Variance Explained

\begin{tabular}{|c|c|c|c|c|c|c|}
\hline Component & \multicolumn{3}{|c|}{ Initial Eigenvalues } & \multicolumn{3}{|c|}{$\begin{array}{l}\text { Extraction Sums of Squared } \\
\text { Loadings }\end{array}$} \\
\hline $\begin{array}{l}\text { (not specific } \\
\text { questions) }\end{array}$ & Total & $\begin{array}{c}\% \\
\text { Variance }\end{array}$ & $\begin{array}{c}\% \\
\text { Cumulative }\end{array}$ & Total & $\begin{array}{c}\% \\
\text { Variance }\end{array}$ & $\begin{array}{c}\% \\
\text { Cumulative }\end{array}$ \\
\hline 1 & 7.145 & 32.476 & 32.476 & 7.145 & 32.476 & 32.476 \\
\hline 2 & 4.038 & 18.356 & 50.832 & 4.038 & 18.356 & 50.832 \\
\hline 3 & 2.890 & 13.135 & 63.968 & 2.890 & 13.135 & 63.968 \\
\hline 4 & 2.594 & 11.792 & 75.760 & 2.594 & 11.792 & 75.760 \\
\hline 5 & 2.024 & 9.201 & 84.961 & 2.024 & 9.201 & 84.961 \\
\hline 6 & 1.391 & 6.323 & 91.284 & 1.391 & 6.323 & 91.284 \\
\hline 7 & .866 & 3.938 & 95.222 & & & \\
\hline 8 & .633 & 2.878 & 98.101 & & & \\
\hline 9 & .299 & 1.358 & 99.459 & & & \\
\hline 10 & .119 & .541 & 100.000 & & & \\
\hline 11 & 3.10E-016 & $1.41 \mathrm{E}-015$ & 100.000 & & & \\
\hline 12 & 2.33E-016 & 1.06E-015 & 100.000 & & & \\
\hline 13 & 1.93E-016 & 8.77E-016 & 100.000 & & & \\
\hline 14 & 8.78E-017 & 3.99E-016 & 100.000 & & & \\
\hline 15 & 3.87E-017 & 1.76E-016 & 100.000 & & & \\
\hline 16 & 1.85E-018 & 8.42E-018 & 100.000 & & & \\
\hline 17 & $-1.50 E-017$ & $-6.80 E-017$ & 100.000 & & & \\
\hline 18 & $-9.29 E-017$ & $-4.22 E-016$ & 100.000 & & & \\
\hline 19 & $-1.40 E-016$ & $-6.38 E-016$ & 100.000 & & & \\
\hline 20 & -1.96E-016 & -8.90E-016 & 100.000 & & & \\
\hline 21 & $-2.33 E-016$ & $-1.06 \mathrm{E}-015$ & 100.000 & & & \\
\hline 22 & $-2.93 E-016$ & -1.33E-015 & 100.000 & & & \\
\hline
\end{tabular}

Note. Extraction Method: Principal Component Analysis.

The data were entered into SPSS and a principal component analysis was conducted. Six components resulted from the Extraction Method of the Principal Component Analysis. Component 1 had the highest loading accounting for $32.47 \%$ of the variance, which was identified as school and academics. Once the factors were determined, the items belonging to each component were summed and correlational analyses were performed on the components to investigate relationships between the subscales. Table one lists the loading of the 6 components from the analysis of the data from the 22 questions.

Table two lists the extractions of the 6 components, with each of the 22 questions listed in order of the variance. VAR000111 is survey question 11, and VAR00012 is survey question 12 . Component column 1 with the entries of .911, .830, .747, .737, .718, -.702, .693, -.682, -.627, .588, and .522 sequentially 
illustrate the highest component loading of 11 specific survey questions, with .911 being the largest variable question from the component 1 entries.

Table 2. Component Matrix(a)

\begin{tabular}{|l|c|c|c|c|c|c|}
\hline & \multicolumn{7}{|c|}{ Component } \\
\hline Questions 1- 22 & 1 & 2 & 3 & 4 & 5 & 6 \\
\hline VAR00011 & .911 & -.031 & -.113 & .128 & .000 & .259 \\
VAR00012 & .830 & .316 & -.189 & -.193 & .225 & -.143 \\
VAR00005 & .747 & -.098 & .222 & -.399 & .308 & .107 \\
VAR00010 & .737 & .448 & -.018 & .047 & .292 & .344 \\
VAR00009 & .718 & -.611 & .252 & -.094 & -.025 & .011 \\
VAR00018 & -.702 & -.441 & .002 & -.376 & .277 & .132 \\
VAR00015 & .693 & .088 & -.162 & .102 & -.355 & -.419 \\
VAR00016 & -.682 & -.056 & .132 & -.175 & .661 & -.067 \\
VAR00013 & -.627 & .364 & .275 & .537 & .175 & -.040 \\
VAR00002 & .588 & -.274 & -.103 & .375 & -.453 & .384 \\
VAR00001 & .552 & .536 & -.329 & .015 & .083 & .307 \\
VAR00017 & .232 & .837 & -.090 & -.109 & .082 & -.256 \\
VAR00019 & .180 & .748 & .582 & -.083 & .058 & -.200 \\
VAR00008 & .460 & -.726 & .267 & .329 & .166 & -.009 \\
VAR00007 & .585 & -.610 & -.080 & .274 & .434 & -.067 \\
VAR00020 & .109 & -.406 & .833 & .043 & -.073 & -.269 \\
VAR00021 & .094 & .113 & .791 & -.380 & -.115 & .328 \\
VAR00003 & -.047 & .202 & .707 & .382 & -.083 & .304 \\
VAR00022 & .487 & .247 & .342 & -.673 & .029 & .062 \\
VAR00014 & -.444 & .390 & .073 & .614 & .217 & .394 \\
VAR00004 & .462 & .244 & .343 & .595 & -.038 & -.424 \\
VAR00006 & .464 & -.049 & -.085 & .283 & .781 & -.108 \\
\hline
\end{tabular}

Note. Extraction Method: Principal Component Analysis; 6 components extracted.

The resulting analyses showed significant correlations between academics and employment $(r$ [87]= $.622, p=.000)$, academics and opportunity $(r[89]=.217, p=.039)$, and challenge and opportunity $(r[88]=.302, p=.004)$. From these 4 themes of school and academics, satisfaction with academic programs, employment, and workplace opportunities with challenges, strong correlations existed between academics and employment, academics and opportunity, and challenges and opportunity. Academics had the strongest correlations from all of the themes.

Next, a series of independent samples $t$-tests were run with the same SPSS program to see whether there were any differences between the subscale items of captains and first officers for the 4 themes of school and academics, satisfaction with academic programs, employment, and workplace opportunities with challenges. The results from conducting the series of $t$-tests on these variables of interest showed that there were no significant differences between the captains and first officers on three of these themes. However, the $t$-test did show a statistically significant difference for the theme of opportunity in the comparison between captains and first officers $(t(89)=3.134, p=.002)$. This gave a distinct advantage to first officers scoring higher in the opportunity theme than the results scored for the captains. 


\section{Demographic Research-Related Data Questions}

The data section of the survey had questions pertaining to the background of the pilots taking the survey. Questions 23 through 47 asked for descriptive information that pertained to school/academics and present employment. Most of the pilots completed this data section, and their answers could be cross-referenced with other questions in the data section.

Questions 23 and 24 qualified the pilots' sex and age. Of the 91 respondents, 87 were male (96\%), with an average age of $37.80(S D=9.54$ years $)$.

Table 3. Independent Samples t-Tests

\begin{tabular}{llllll}
\hline Variable & $t$ & $d f$ & $p$ & Mean Difference & SE \\
\hline Academics & 1.929 & 89 & .057 & 2.47 & 1.28 \\
Employment & 1.430 & 87 & .156 & 1.14 & 0.79 \\
Opportunity & 3.134 & 89 & $.002^{*}$ & 1.24 & 0.39 \\
Other & 1.170 & 88 & .245 & 0.49 & 0.42 \\
\hline$*<05$ & & & & &
\end{tabular}

$*<.05$

Question 26 dated the pilots' entry into aviation by asking for the date of first solo. The date was converted into years and months from the earliest time listed and subtracted from the most recent date of September 2007. This gave the average number of years that the pilots had been flying at 16.92 years $(S D=9.57)$. This is also a level of experience data indication.

Question 27 asked for the total flight hours that the pilots had accrued. The combined captains and first officers had an average total flight time of 7,693 hours $(S D=5515.94)$. This flight time could be further broken down between first officers and captains in order to reflect the total experience of the different pilot flight positions. This question could also be analyzed with other questions, such as question 33, in order to collect additional data on the time pilots have accrued since being employed at their present airline. This would better qualify the experience level that pilots have in the workplace today.

Questions 28 and 29 asked for CFI Certificate and total CFI time (Certified Flight Instructor). These questions qualify the background of the individual taking the survey in relation to how they built their flight time during and after their academic flight training. They also indicate the process of how crew coordination is learned between 2 pilots in one airplane. Out of the 91 respondents, $78(85.7 \%)$ had their CFI rating, and total CFI flight hours were 1,663.

Questions 32, 33, and 34 helped qualify the employment requirements of the employers for the pilots taking the survey. These numbers can be analyzed as a benchmark that employers establish for pilots to qualify for employment consideration with specific flight times.

Question 33 compares and contrasts the years that pilots have been employed at the specific regional airline and in the capacity of captain or first officer. This number is valuable to determine the new hire rate, upgrade time from first officer to captain, and attrition rate at the specific regional airline. Of the 91 respondents, 49 (53.8 \%) were captains and 42 (46.1\%) were first officers. Captains indicated that they 
had been employed at the specific regional airline for an average of 17.3 years, and first officers had been employed for an average of 4.5 years $(S D=6.87)$.

Question 36 measured the highest level of education that the pilots had completed. The entry for bachelor's degree had the highest completion rate of all the levels measured. Out of 91 respondents, 64 (70.3\%) attained the bachelor's degree. No other degree selections came close to this figure.

Questions 38 through 47 were queries into specific collegiate data fields. Significant high percentage numbers from these questions help determine the quality of the collegiate program that prepared respondents for their regional airline careers.

Question 38 gives information on the connection of bridge programs between regional airlines and aviation universities. This is invaluable information pertaining to the importance of regional airlines being involved in the training process with higher education aviation programs. Out of 91 respondents, 12 (13.1\%) graduated from a bridge program for a regional airline. Question 40 is extremely valuable because it measures the number of pilots who obtained an aviation degree from higher education aviation programs. Out of 91 respondents, 53 (58.2\%) obtained an aviation degree. The last question, 47, is an indicator of how flight schools directly control the access and use of training aircraft. Out of 91 respondents, 75 individuals (82.4\%) indicated that the school owned their own aircraft.

\section{Survey Respondents’ Comments With Qualitative Data Themes}

All of the recorded written comments that respondents left on their surveys were compared for similarities to the 4 themes that were correlated from the quantitative data of the first 23 questions of the survey. The themes that emerged were school and academics, satisfaction with academic programs, employment, and workplace opportunities with challenges. Of these themes, academics were the predominant concern in the comments.

\section{RESULTS}

Three research questions were examined to expose any perceived inadequacies in higher education aviation curriculum, and to compare and contrast the role of 2-year colleges with aviation programs to the role of 4-year universities with aviation programs.

\section{Research Question 1: Is higher education advisable for students embarking on an aviation career as a pilot for a regional airline?}

Responses from the first 22 Quantitative Research questions had academics with the most correlations. In this section, First Officers scored higher responses than Captains. Captains responded more frequently in the Disagree areas of these questions. Responses from the Data Research questions had a high percentage of results in academic areas. $70.3 \%$ had a Bachelor's Degree, with $58.2 \%$ completing an aviation degree. The high percentage response for completing a Bachelor's Degree confirmed the need and perceived requirement for higher education in a regional airline career. Responses from the Respondent's Comments questions had mixed results, but the majority left favorable remarks on the importance of obtaining a degree to improve pilot chances of being hired in the regional airline industry. First Officers left the most favorable responses to the value of their higher education degrees and were the most adamant about obtaining their present employment due to higher education. 


\section{Research Question 2: Have 2-year colleges and 4-year universities with aviation programs kept up}

with the requirements for employability with the regional airlines?

Responses from the first 22 Quantitative Research questions had employment opportunities as a high return. Reponses in this area indicated a majority satisfaction with employment opportunities that were created by higher education aviation programs. Responses from the Data Research questions were limited in being related to this research question, but several questions indicated some response to higher education aviation programs being current for the needs of regional airlines. Responses from the Respondent's Comments questions dealt mostly with staffing shortages and workplace conditions. However, the few comments that were made on employability that was due to higher education aviation programs were favorable.

\section{Research Question 3: Can higher education aviation programs properly measure and critique their programs in regard to the qualifications that students need to embark on a career as a regional airline pilot?}

There were responses from the first 22 Quantitative Research questions that were interpreted to critique and measure higher education programs. These questions dealt with training accountability and how the respondent felt they had an advantage in being hired by the regional airlines. Most of the responses were made in the Strongly Agree section, and this verified the research question of aviation colleges being able to critique their programs. Responses from the Data Research questions were limited in making connections to aviation college accountability due to the nature of the questions, and no real connections could be made. Responses from the Respondent's Comments questions had numerous direct connections to the merit, worth and accountability of higher education aviation programs in reference to preparing aviation students for the regional airlines. The comments dealt with schools that were accountable in the preparation for students being adequately trained for the airlines, and comments were mixed in the esteem held for former colleges. Comments made ranged from avoiding over-priced schools, advantages of formal ground courses, the lack of college job placement, and the lack of a formal CFI (Certified Flight Instructor) school. The overall response was that higher education aviation programs can properly measure and critique their programs if they desire to meet the needs of their students.

\section{DISCUSSION}

Pilot needs by the regional airlines over the last decade have challenged collegiate aviation to produce enough pilots to meet their future staffing requirements. Out of this need, allowances have been made by the airlines to accelerate the process in which qualified pilots can be hired and trained to meet the standards required by the FAA and regional airline training departments. In this environment, 2-year colleges and 4-year universities with aviation programs have had to compete with outside markets to qualify, train, and graduate a better student product that is ready to be integrated into the regional airlines. Today's aviation graduates will have to blend with older pilots who were trained differently in the past and must bridge the gaps that exist between the new and the old procedures of getting started in the regional airline industry.

The majority of the pilots completing the survey had a 4-year degree (70.3\%). This was common from new hires to much older experienced captains. By tabulating the results, the 4-year degree is still the standard that pilots desire to obtain, although the major of aviation is inconclusive; $58.2 \%$ possessed a 4 year aviation degree. Those who responded to the subject of degree specialty were split on whether the type of degree was important. 
Several captains were impressed with the quality and caliber of training that new hires possessed, but they were concerned about the lack of total flight time and lack of outside experience of the younger first officers hired. First officers surveyed were far more optimistic about their future and displayed a higher level of confidence in the attainment of their flight positions. The first officers also had a greater appreciation of their higher education backgrounds and expressed an opinion that this background was a deciding factor on their being hired at their airline. The first officers also gave favorable remarks concerning the level of training they received at their collegiate flight schools, whereas many captains came from nontraditional flight schools that were not associated with higher education. Pilots completing the surveys gave their aviation colleges and aviation universities favorable remarks for curriculum, technical expertise, and modernization for aeronautical training. This pattern was even higher with first officers.

The survey showed no alarming levels of inadequacies that existed in the higher education aviation curricula, nor did it find that major changes were needed to better qualify aviation students in the hiring process at regional air carriers. Most comments made on issues of past training came from concerns about the expenses incurred and the burden of repaying large student loans. Pilots have traditionally gained experience after graduation when they have the aviation certificates and ratings obtained at their respective aviation colleges and universities. These same colleges and universities often employ their graduates as Certified Flight Instructors to gain experience by training other students.

There was little difference found in pilots' preferences of 2-year colleges with aviation programs when compared to 4-year universities with aviation programs in the process of how students were educated for aviation flight careers. The surveys showed that the majority of the pilots with aviation degrees graduated with a 4-year degree, but the 2-year degree graduates spoke very favorably of their aviation schools.

One captain recommended that a new collegiate course of study should be created to help students plan and forecast their seniority with prospective air carriers. This course would include a research of the pilot age group broken down by percentage, a forecast of retirees in each year over the next ten years, a research of the industry growth cycle, a tabulation of the entire industry growth cycle, and the anticipated student age when hired by the 14 CFR Part 121 operator of their choosing.

Many findings in the analysis of the survey and the comments from the respondents found issues parallel to those stated in the review of the literature. Some of these examples were the mentioning that collegiate aviation has been a major source of training in the United States, and that the downsizing of the military has led to a dependence on the civilian field. Other parallels were the lowering of standards for entry-level pilots by the regional airlines in times of pilot shortages and the concern that regional airlines are desperately trying to recruit enough pilots to meet their staffing requirements.

\section{RECOMMENDATIONS}

As hiring criteria for regional airlines change, higher education will confer an advantage to students seeking employment with an air carrier, but the training process must continue to be tailored to meet the needs of the air carriers' workplaces. Ground school curricula and flight courses must be coordinated to meet the present day needs of the regional airlines, and agreements must be in place between the airlines and the curricula of the aviation schools to meet the needs and demands of the airline industry. The superior package of an aviation college degree offers the combined package of aviation training and college core components to provide this training for a career in the air carrier industry.

The choice students make in pursuing an aviation career at an early age is a challenge. They must take the correct steps to successfully accomplish the dream of flying, but it is also vital that they make the ideal academic choices for preparation in this career. The major commitment students make to pursue an 
airline career must be approached as steps toward a career in air carrier operations, not a weekend hobby that must be supported by another job.

To offer a quality product in the training field, 2-year colleges and 4-year universities with aviation programs must increase their offerings for CFI programs, and they must push for a higher completion rate. The process of creating a quality degree program to obtain the CFI rating that is more accessible to aviation students must be implemented in a larger number of higher education aviation programs.

Academic degree plans with minors outside of aviation give prospective students an insight into additional fields. Further higher education in graduate fields is also an option, with master's degrees being obtainable through distance learning programs that are more accessible to pilots. This type of diversification makes aviation students more competitive in not only the air carrier industry but in other facets of aviation as well.

Future studies could explore how regional airlines could tailor specialized pilot training agreements with 2-year colleges and 4-year universities with aviation programs, both academically and financially. Added incentives for the student could be financial aid, flight time building grants, and a higher initial salary upon being hired by the airline after the student graduates. This could add needed resources to the schools to better qualify potential students from the onset of training and eliminate lost time and financial resources.

\section{CONCLUSION}

Two-year colleges and 4-year universities with aviation programs are meeting the demands made by the regional airlines, but pilot shortages of the past have presented challenges to the system to produce more pilot graduates in less time. Disparities exist between older crew members and younger, less experienced new-hires because of the demands of the staffing shortage of the regional airlines. With this shortage, the pressing issues of how to train and hire qualified pilots to fly technologically advanced regional airline jet aircraft have forced the industry to demand more aviation skills from a shrinking market of aviation pilot candidates.

Aviation students recognize the worth and value of a 4-year degree and that obtaining this degree creates a distinct marketing advantage in being hired by both the regional airlines and later legacy major airlines. Also, there is an advantage in obtaining a 4-year aviation degree because of the experience gained in a collegiate aviation environment. 


\section{REFERENCES}

Banard, K. R. (2000 April). Ascend to flight training. Tech Directions, 59(9), 26.

Clark, J. (2006). The face of collegiate aviation: Factors impacting self-selection of collegiate aviation programs. Collegiate Aviation Review, 24(1), $42-57$.

Damos, D. (1996). Pilot selection batteries: Shortcomings and perspectives. International Journal of Aviation Psychology, 6(2), 199.

Dennison, G. M. (2003). Privatization: An unheralded trend in public higher education. Innovative Higher Education, 28(1), 7-20.

Fanjoy, R. O., Young, J. P., \& Dillman, B. G. (2005). Exit exams for college flight programs: Redundant activity or certification of competency? Collegiate Aviation Review, 23(1), 24-31.

Fanjoy, R. O., Young, J. P., \& Suckow, M. W (2006). The experience factor: A regional airline view of pilot candidate qualifications. Collegiate Aviation Review, 24(1), 67- 72.

Flouris, T. C. (2001). The impact of ground schools in a collegiate aviation program on FAA written exam scores. Collegiate Aviation Review, 19(1), 49-61.

Gilbert, G. A. (1994). U.S. regional airlines report substantial growth. Business \& Commercial Aviation, 75, 20.

Hedge, J. W., Bruskiwicz, K. T., Borman, W. C., Hanson, M. A., Logan, K. K., \& Siem, F. M. (2000). Selecting pilots with crew resource management skills. International Journal of Aviation Psychology, 10(4), 377-392.

Hunt, J. R. (1972). The role of the aviation university. Education, 92(4), 2-4.

Lindseth, P. A. (1999). Assessing the environment and outcomes of 4-year aviation programs: Does program quality make a difference? Collegiate Aviation Review, 17(1), 40-52.

Mahesh, S., Chowdhury, M., Colquitt, C., Reyes, P., Bonakdar, N., Ray, J., \& Robles, J. (2005). Distance education in the business aviation industry: Issues and opportunities. Journal of Distance Education Technologies, 3(1), 20-43.

Mangan, K. (2000, January 21). Aviation centers take off as airlines face pilot shortage. Chronicle of Higher Education, 46(20), 47-48.

Matthews, N. (2006, April 17). Alteon formulates multicrew pilot license course in Brisbane for Asian airlines. Aviation Week \& Space Technology, 164(16), 44.

Prather, C. D. (2006). The council on aviation accreditation: Part one- historical foundation. Journal of Air Transportation, 11(2), 156-177.

Ruiz, J. R.(2004). The perceived value of airline flight operations internship activities and/or benefits in the pursuit of career goals. Collegiate Aviation Review, 22(1), 71- 82. 
Schwab, G. L. (2005). An examination of the Indiana State University aerospace administration program. Journal of Air Transportation, 10(10), 72-103.

Several paths available for aviation candidates. (2001, October 8). Aviation Week \& Space Technology, 155(15).

United States Department of Education. (1998, September 14). Taking flight: Education and training for aviation careers. Retrieved from http://www.ed.gov/offices/OUS/PES/higher/civilai2.html

Wolfe, K. (2005a, January 31). Older pilots find not-so-friendly skies. CQ Weekly, 218.

Wolfe, K. (2005b, April 25). Rough skies for the 'big six.’ CQ Weekly, 1068.

Wells, A. T., \& Wensveen, J. G. (2004). Air transportation, a management perspective, ( ${ }^{\text {th }}$ ed.). San Francisco: Thomson Brooks-Cole. 


\section{Regional Airline PILOT SURVEY}

\begin{tabular}{|c|c|c|c|c|c|}
\hline Question & $\begin{array}{l}\text { Strongly } \\
\text { Disagree }\end{array}$ & Disagree & Agree & $\begin{array}{l}\text { Strongly } \\
\text { Agree }\end{array}$ & $\begin{array}{c}\text { Not } \\
\text { Applicabl } \\
\text { e }\end{array}$ \\
\hline $\begin{array}{l}\text { 1. I learned about my flight school through } \\
\text { acquaintances that recommended me this } \\
\text { particular school. }\end{array}$ & 1 & 2 & 3 & 4 & 5 \\
\hline $\begin{array}{l}\text { 2. My initial expectations were met at my flight } \\
\text { school from the time I started flight training to } \\
\text { the completion of my aviation courses. }\end{array}$ & 1 & 2 & 3 & 4 & 5 \\
\hline $\begin{array}{l}\text { 3. I received a good value for the money } \\
\text { I invested at my flight school. }\end{array}$ & 1 & 2 & 3 & 4 & 5 \\
\hline $\begin{array}{l}\text { 4. I was motivated and challenged by my flight } \\
\text { instructors during my flight school training. }\end{array}$ & 1 & 2 & 3 & 4 & 5 \\
\hline $\begin{array}{l}\text { 5. The level of avionics at my basic flight } \\
\text { school was adequate for the basic instrument } \\
\text { skills I use in my present flight position. }\end{array}$ & 1 & 2 & 3 & 4 & 5 \\
\hline $\begin{array}{l}\text { 6. Membership in the Alpha Eta Rho aviation } \\
\text { fraternity was a factor that increased my } \\
\text { aviation marketability. }\end{array}$ & 1 & 2 & 3 & 4 & 5 \\
\hline $\begin{array}{l}\text { 7. My aviation ground school academic subjects } \\
\text { were coordinated to be taken at the same time } \\
\text { I took specific flight courses. }\end{array}$ & 1 & 2 & 3 & 4 & 5 \\
\hline $\begin{array}{l}\text { 8. I was motivated and challenged by my } \\
\text { academic } \\
\text { professors during my aviation classroom } \\
\text { training. }\end{array}$ & 1 & 2 & 3 & 4 & 5 \\
\hline $\begin{array}{l}\text { 9. My basic non-aviation academic core } \\
\text { components } \\
\text { were blended well with my aviation curriculum } \\
\text { to } \\
\text { produce a well-rounded degree. }\end{array}$ & 1 & 2 & 3 & 4 & 5 \\
\hline $\begin{array}{l}\text { 10. My school was concerned for my future } \\
\text { marketability in air carrier employment. }\end{array}$ & 1 & 2 & 3 & 4 & 5 \\
\hline $\begin{array}{l}\text { 11. I am satisfied with the amount of time it } \\
\text { took } \\
\text { to complete my aviation degree. }\end{array}$ & 1 & 2 & 3 & 4 & 5 \\
\hline $\begin{array}{l}\text { 12. My academic advisor adequately prepared } \\
\text { me for the air carrier industry where I was later } \\
\text { employed. }\end{array}$ & 1 & 2 & 3 & 4 & 5 \\
\hline 13. I completed most of my aviation training & 1 & 2 & 3 & 4 & 5 \\
\hline
\end{tabular}




\begin{tabular}{|c|c|c|c|c|c|}
\hline $\begin{array}{l}\text { outside } \\
\text { of the college where I received my degree. }\end{array}$ & & & & & \\
\hline $\begin{array}{l}\text { 14. I received my flight training outside of a } \\
\text { university collegiate environment, and I found it } \\
\text { superior to that of an aviation university. }\end{array}$ & 1 & 2 & 3 & 4 & 5 \\
\hline $\begin{array}{l}15 . \text { If I could return to my freshman year, I } \\
\text { would choose the same major I completed with } \\
\text { my degree. }\end{array}$ & 1 & 2 & 3 & 4 & 5 \\
\hline $\begin{array}{l}\text { 16. Distance learning was an important factor in } \\
\text { completing my college degree. }\end{array}$ & 1 & 2 & 3 & 4 & 5 \\
\hline $\begin{array}{l}\text { 17. Based on my collegiate training, I was well } \\
\text { prepared for my interview with my present } \\
\text { employer. }\end{array}$ & 1 & 2 & 3 & 4 & 5 \\
\hline $\begin{array}{l}\text { 18. My academic background had no factor on } \\
\text { my } \\
\text { being selected by my present airline. }\end{array}$ & 1 & 2 & 3 & 4 & 5 \\
\hline $\begin{array}{l}\text { 19. My college training and degree put me at an } \\
\text { advantage over applicants with no college } \\
\text { training } \\
\text { when I was hired by my current employer. }\end{array}$ & 1 & 2 & 3 & 4 & 5 \\
\hline $\begin{array}{l}\text { 20. I was hired at this airline due to my } \\
\text { trainability } \\
\text { in aviation skills. }\end{array}$ & 1 & 2 & 3 & 4 & 5 \\
\hline $\begin{array}{l}\text { 21. I was hired at this airline due to my past } \\
\text { operational background in aviation. }\end{array}$ & 1 & 2 & 3 & 4 & 5 \\
\hline $\begin{array}{l}\text { 22. Based on my past training at my aviation } \\
\text { school, } \\
\text { I am satisfied with my current aviation status. }\end{array}$ & 1 & 2 & 3 & 4 & 5 \\
\hline
\end{tabular}

23. Sex: $\mathrm{M}_{-} \mathrm{F}$

24. Age:

25. Race:

26. Date of first solo:

27. Total flight hours:

28. CFI Certificate: YES NO

29. Hours as CFI:

30. Part 135 Hours:

31. Part 91 Corporate Hours: 
32. Number of hours when hired by present airline:

Single Engine: Multi Engine:

Turbine Engine:

33. Years employed at present airline:

34. Present Flight Position:

35. Former military pilot: YES NO

36. Education, please check the highest level completed:

High School Some College Associate's Degree

Bachelor's Degree Graduate School Experience Graduate School Degree

37. Name of college/university:

38. Graduate of college with bridge program for regional airline: YES NO

39. Completed college airline internship: YES NO

40. Aviation Degree: $\quad$ YES NO

41. Non Aviation Degree: $\quad$ YES NO

42. 2 year college with aviation school: YES NO

43. 4 year university with aviation school: YES NO

44. Aviation school, no college affiliation: YES NO

45. Part 141 curriculum: $\quad$ YES NO

46. Part 61 curriculum: $\quad$ YES NO

47. Were aircraft owned by aviation school? YES NO 